\title{
Hans Nordeng: a man of principles
}

\author{
Anders Klemetsen
}

Received: 29 November 2010 / Accepted: 16 March 2011 / Published online: 6 April 2011

(C) The Author(s) 2011. This article is published with open access at Springerlink.com

\section{Keywords Obituary}

Professor, cand. real. Hans Nordeng died in Bærum, Norway in May 2010, at the age of 91 years. He was an extraordinary man; an unconventional, creative and hard-working scientist, and a very gifted teacher and tutor. Most of his publications were based on many years of research, often combining extensive field work and carefully planned experiments and transplantations (Vøllestad and Skurdal 1994). Several of them contributed significantly to the fields of fish ecology and evolution. He kept a glowing enthusiasm for fish biology until a great age, publishing his last paper when he was 91 (Nordeng 2009).

He grew up in Salangen, Northern Norway, close to the river that was to become the primary research system of his career. As a young recruit at an under-officer school, he fought in the battle at the Narvik-Gratangen front of World War II in the spring of 1940. He started a military career after the war but later went to university as a grown-up man. After graduation, he held an assignment with the Institute of Marine Research in Bergen before taking up a lectureship at the University

A. Klemetsen $(\bowtie)$

Department of Arctic and Marine Biology,

University of Tromsø,

9037 Tromsø, Norway

e-mail: anders.klemetsen@uit.no of Oslo, a position he kept for most of his active life. Then, after retiring from Oslo, he was appointed as a full professor at the University of Tromsø, finally achieving the personal chair he so much deserved. He served in this position for 2 years.

Hans Nordeng published several innovative and influential papers. Two of them will always be tied to his name. The first, published in Nature (Nordeng 1971), proposed a pheromone hypothesis to explain the population specific homing of anadromous fishes to their native river. It was based on transferring fertilized eggs of anadromous arctic charr (Salvelinus alpinus) from the Salangen River system to a hatchery at Voss, south-west Norway (south of the range of anadromous charr), rearing the fish to the smolt stage (4 years), flying them back to northern Norway and releasing them in the estuaries of the Salangen River and a neighbouring river. These fish had experienced no olfactory cues from their home river water during rearing. Yet almost all the fish that were released in Salangen and the majority of the fish released in the other river, returned to the Salangen River. This strongly suggested that population specific pheromones, possibly bound to the skin mucus, provided the olfactory cues for homing; not the river water itself. He established important co-operation with physiologists to test the hypothesis (Døving et al. 1974), and successive pheromone research included several other migratory fish species. The second paper (Nordeng 1983) was based on his long-term studies of three sympatric 


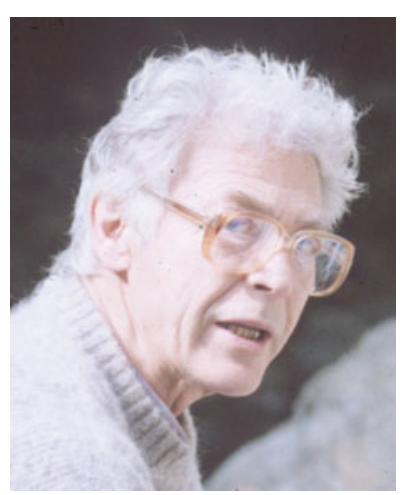

Fig. 1 Hans Nordeng, during an excursion to study Japanese charr after the international symposium in 1988 (photograph by David L. G. Noakes)

morphs of arctic charr (two resident, one anadromous) in the Salangen River system, and included extensive rearing experiments in the hatchery at Voss and also cross-transplantations. From that, he concluded that sympatric charr morphs are phenotypic variants within the same population because he found that parents of the three Salangen morphs produced offspring of all three kinds in the lab. Furthermore, a tagged individual fish could transform from one morph to another during its lifetime. This study formed an important basis for later theoretical models for ecologically based speciation in postglacial fishes (Adams 1999; Snorrason and Skulason 2004).

Science sometimes produces personalities that are not only exceptional researchers but also gifted teachers. Hans Nordeng was such a person (Fig. 1). He attracted a large group of talented students and his group in Oslo grew to a veritable school in freshwater fish ecology, physiology, genetics and evolution. Many of his students took up, and still occupy, central positions in Norwegian fish management agencies, research institutes and universities. Several became highly productive scientists. Not only his own research, but also the personal inspiration he gave his students and colleagues will therefore influence
Norwegian and international fish biology for a long time (Nordeng 1989).

Hans Nordeng left his wife, Åse, and their daughter Siri. Åse was his closest friend and supporter, and a skilled assistant in his research efforts throughout his career. Our sincere thoughts are with them in this difficult time.

Open Access This article is distributed under the terms of the Creative Commons Attribution Noncommercial License which permits any noncommercial use, distribution, and reproduction in any medium, provided the original author(s) and source are credited.

\section{References}

Adams CE (1999) Does the underlying nature of polymorphism in the arctic charr differ across the species? Int Soc Arct Charr Fanatics Info Ser 7:61-67

Døving KB, Nordeng H, Oakley B (1974) Single unit discrimination of fish odours released by char (Salmo alpinus L.) populations. Comp Biochem Physiol 47A:1051-1063

Nordeng H (1971) Is the local orientation of anadromous fishes determined by pheromones? Nature 233:411-413

Nordeng H (1983) Solution to the 'char problem' based on arctic char (Salvelinus alpinus) in Norway. Can J Fish Aquat Sci 40:1372-187

Nordeng H (1989) Salmonid migration: Hypotheses and principles. In: Brannon EL, Jonsson B (eds) Proceedings of the salmon migration and distribution symposium. University of Washington, School of Fisheries, Seattle, pp 1-8

Nordeng H (2009) Char ecology. Natal homing in sympatric populations of arctic char Salvelinus alpinus (L.): roles of pheromone recognition. Ecol Freshw Fish $18: 41-51$

Snorrason SS, Skulason S (2004) Adaptive speciation in northern freshwater fishes. In: Dieckmann U, Doebeli M, Metz JAJ, Tautz D (eds) Adaptive speciation. Cambridge University Press, Cambridge, pp 210-228

Vøllestad LA, Skurdal J (1994) Significance of Hans Nordeng's scientific activity. Fauna (Oslo) 47:4-7 (in Norwegian) 